\title{
Earthquake-induced habitat migration in a riparian spawning fish: implications for conservation management
}

\author{
Shane Orchard ${ }^{1,2 *}$ \\ Michael J. H. Hickford ${ }^{2}$ \\ David R. Schiel ${ }^{2}$ \\ ${ }^{1}$ Waterways Centre for Freshwater Management, University of Canterbury and Lincoln University, \\ Christchurch, New Zealand \\ ${ }^{2}$ Marine Ecology Research Group, University of Canterbury, Christchurch, New Zealand \\ * corresponding author \\ Email: s.orchard@waterlink.nz
}

Keywords

Habitat migration, earthquake response, adaptation, waterway management, conservation planning, protected areas, Galaxias maculatus, New Zealand.

\begin{abstract}
Galaxias maculatus is a riparian spawning fish that supports an important recreational fishery in New Zealand with spawning habitat requirements strongly structured by salinity gradients at rivermouths. This study reports changes to the spawning habitat following a series of large earthquakes that resulted in widespread deformation of ground surfaces in the vicinity of waterways. Assessments of habitat recovery focussed on two rivers systems, the Avon and Heathcote, with pre-disturbance data available over a 20 year period. Recovery dynamics were assessed by field survey and mapping of spawning habitat prior to and on seven occasions after the disturbance event. Riparian land-use and management patterns were mapped and analysed using overlay methods in GIS. Habitat migration of up to $2 \mathrm{~km}$ occurred in comparison to all previous records and several anthropogenic land uses have become threats due to changed patterns of co-occurrence. Incompatible activities now affect more than half of the spawning habitat in both rivers, particularly in areas managed for flood control purposes and recreational use. The results are an example of landscape scale responses to salinity and water level changes driven by tectonic dynamics. These dynamics are not the source of the stress per se, rather, they have increased exposure to pre-existing stressors. The case illustrates important principles for managing subtle, yet widespread, change. Adaptive conservation methods and investments in information are priorities for avoiding management failure following environmental change.
\end{abstract}




\section{Introduction}

\section{Earthquake recovery context}

The Canterbury region of New Zealand was affected by a sequence of major earthquakes in 2010 and 2011. The most devastating of these was a $M_{w} 6.3$ earthquake centred beneath the city of Christchurch that caused widespread damage and loss of life (Quigley et al., 2016). After six years of recovery activities the process has entered a more strategic phase. The focus is now on longer term adaptation to environmental and societal change. Important land-use decisions remain for many geographical areas and with regards to many aspects of the natural and built environment. Examples relevant to waterway management include responses to water quality, erosion, flood risk and coastal inundation issues, and the potential re-zoning of large tracts of floodplain and riparian land. Existing statutory arrangements apply to many of the recovery planning requirements and identify institutional responsibilities. Due to the scale and impact of the event bespoke legislation was created to facilitate recovery. Organisations involved include new planning entities with specific tasks (Regenerate Christchurch, 2017) and a wide range of interests across central, regional, and local government, nongovernmental organisations, and local community groups.

Initially, urgent decisions were made to address risks to property and life, and to reinstate essential infrastructure. Remaining decisions have the benefit of more time. There is a unique opportunity to secure benefits through earthquake recovery planning in relation to historical degradation of natural environments and improved resilience to future events. Natural values in the affected areas have thus far received less attention, but include traditional cultural uses such as the wild harvest of food and fibre (Jolly \& Ngā Papatipu Rūnanga Working Group, 2013; Lang et al., 2012), risk reduction functions (Orchard, 2014), and habitat for many indigenous and migratory species with protected status. However, knowledge gaps are a barrier to securing benefits through the planning process. Information requirements include quantifying impacts of the earthquakes and identifying opportunities for future gains.

\section{Spawning habitat of īnanga}

In the present study, our particular focus is Galaxias maculatus, or 'īnanga', a riparian spawning fish. G. maculatus is an amphidromous species currently listed as 'at risk - declining' in the New Zealand Threat Classification System (Goodman et al., 2014). Reversing the decline of inanga is addressed in many statutory documents as well as non-statutory plans and is a priority issue for Māori. Juvenile fish are harvested in an iconic recreational and culturally important fishery (McDowall, 1984). The harvest of inanga and other 'whitebait' species creates an ongoing tension between conservation and sustainable use. However, use and non-use interests share the objective of enhancing inanga populations. The protection of spawning habitat is an urgent and practical goal due to a history of degradation associated with land-use changes near lowland waterways (McDowall, 1992; McDowall $\&$ Charteris, 2006).

Inanga has a specialised reproductive strategy that is synchronised with the spring tide cycle which strongly influences the distribution of spawning sites (Burnet, 1965). Spawning sites occur close to the maximum upstream extent of saltwater intrusion and occupy only a narrow elevation range (Taylor, 2002). Eggs are laid in riparian vegetation just below the spring tide high-water mark and hatch in response to inundation after a 2-4 week development period (Benzie, 1968b). The composition and condition of riparian margins at these specific sites is critical to spawning success (Hickford \& Schiel, 2011a). 
This specificity suggested that earthquake-induced land deformation could affect habitat in several ways. First, disturbance could reduce the availability or condition of existing spawning sites, and enduring changes might result from vegetation recovery effects. Second, large scale impacts were possible due to physicochemical effects. This was the particular focus of our study in light of suspected earthquake-driven hydrodynamic changes and the reported structuring of habitat by salinity (Richardson \& Taylor, 2002; Taylor, 2002). Because there was no prior salinity baseline available, our focus was direct detection of changes in the distribution of spawning sites. By reconstructing a spawning site distribution baseline using data from previous studies, this comparison was possible for the consideration of earthquake effects. The objectives of the study were therefore to quantify the preand post-quake spawning site distribution against riparian land uses and evaluate distributional effects to identify management implications.

\section{Methods}

\section{Study area}

The two study catchments are the Avon River (Ōtākaro) and Heathcote River (Ōpāwaho) (Figure 1). These are spring-fed, lowland waterways with small average base flows (approx. 2 and 1 cumecs respectively) originating within the city of Christchurch, New Zealand (White et al., 2007). The catchments are heavily urbanised, particularly in their upstream reaches. The two waterways are often channelized through the use of bank stabilisation engineering and flow regulation structures including flood-gates. The lower catchments are characterised by extensive wetlands and saltmarsh areas that comprise the Avon-Heathcote Estuary / Ihutai (Figure 1). These are remnants of a larger and relatively mobile ecosystem of coastal hydrological features (Kirk, 1979).

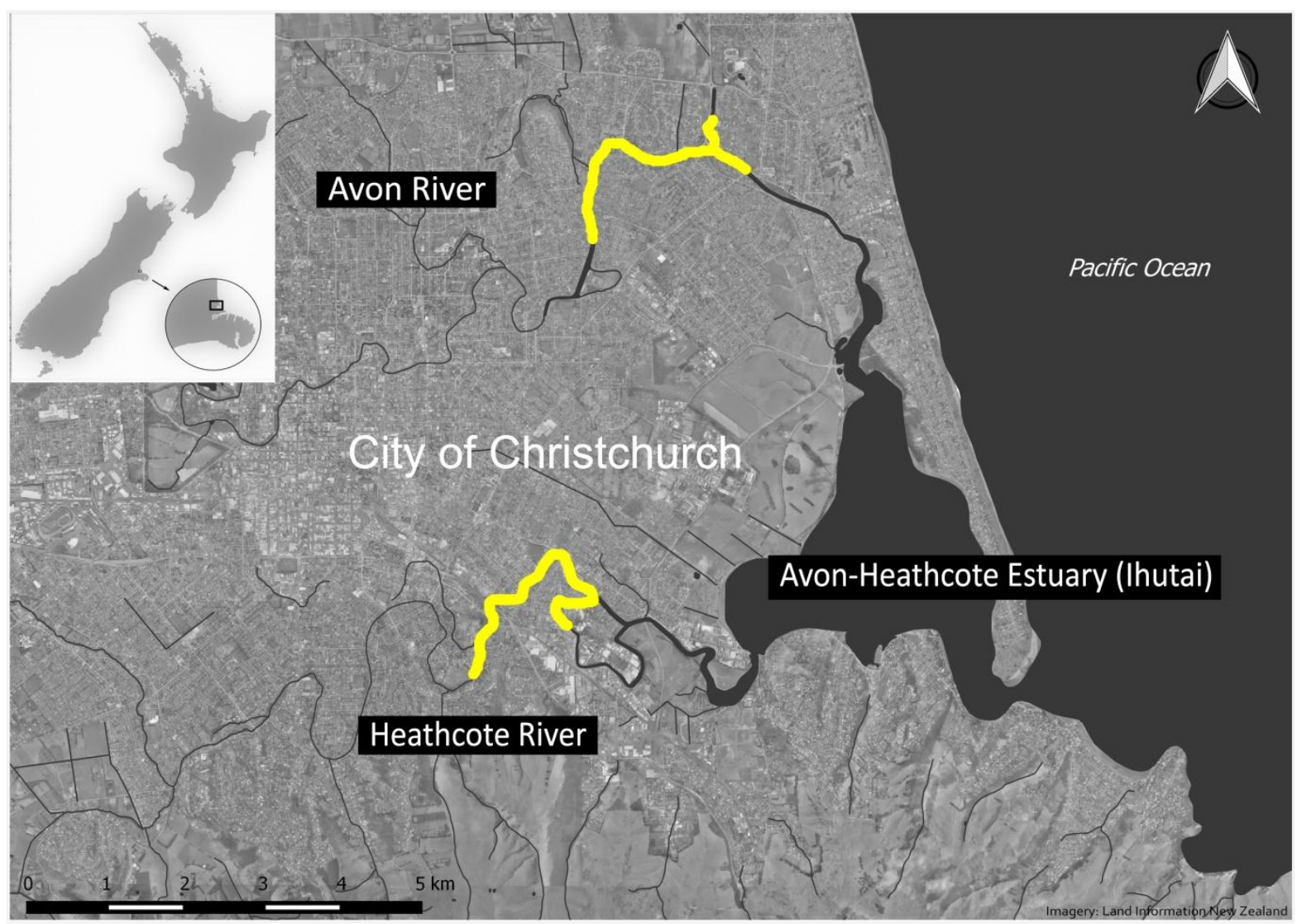

Figure 1. Location of the Avon and Heathcote Rivers in Christchurch, New Zealand, showing reaches surveyed for inanga spawning in the post-quake studies (in yellow). 
Vertical seismic shifts and lateral spread were pronounced in the vicinity of Christchurch waterways particularly towards the estuary (Hughes et al., 2015). Changes in ground levels in and around the estuary were in the order of $\pm 0.5 \mathrm{~m}$ with a trend towards uplift in the south and subsidence in the north (Beaven et al., 2012). Hydrodynamic modelling of the estuary showed extensive bathymetric change and an estimated 15\% reduction in the estuarine tidal prism (Measures et al., 2011).

\section{Pre-earthquake baseline}

A literature review was completed to identify pre-quake spawning records augmented with information from current researchers (M. Taylor, S. McMurtrie, C. Meurk, pers. comm.) and records from the National Īnanga Spawning Database (www.inangaconservation.nz). Historical spawning site data were restricted to sites identified through the observation of eggs in riparian vegetation. All information was digitised in GIS by identifying coordinates for upstream and downstream extents from maps, photographs or co-ordinates provided in the original reports. Where this information was not available, locations were estimated using the text descriptions provided. Semi-continuous stretches of spawning were lumped into a single reach in some cases, generally following the description given in the original records.

\section{Post-earthquake studies}

A census-style survey methodology was used with the objective of detecting all spawning occurrences at the catchment scale following the methods of Orchard \& Hickford (2017). The search areas were approximately $4 \mathrm{~km}$ reaches in each river (Figure 1). The survey area extended from the downstream transition to saltmarsh vegetation, which is unsuitable for spawning (Mitchell \& Eldon, 1991), to $500 \mathrm{~m}$ upstream of the inland limit of saltwater. In the Avon this included the confluence with a prominent tributary to the north. The saltwater limit was established using conductivity/temperature loggers (Odyssey, Dataflow Systems Ltd, NZ) deployed during spring tide sequences and additional spot measurements using a handheld conductivity/salinity/temperature meter (YSI Model 30, YSI Inc., USA). The survey period included the peak spawning months (Taylor, 2002) over two years. Surveys commenced five days after the peak tide in the spring tide sequence and followed a set schedule to minimise temporal confounding effects between months (Table S1). Reaches surveyed later in the schedule were more sensitive to egg mortality effects due to the time elapsed since spawning. Results are more likely to underestimate the extent of spawning occurrences in these areas, but are comparable between months.

The search area was surveyed systematically in the first two months of the study by conducting three searches for eggs within contiguous $5 \mathrm{~m}$ blocks along each riverbank. Each search involved opening up the vegetation down to ground level at random locations within the block following a transect line perpendicular to and spanning the high water mark. On subsequent months, the survey effort was reduced to areas of potential habitat following a habitat classification system (Orchard \& Hickford, 2017). Whenever eggs were found, the survey was extended $50 \mathrm{~m}$ either side of the last occurrence to confirm the full extent of the spawning site. Spawning sites were defined as the area occupied by continuous or semi-continuous patches of eggs. Upstream and downstream extents were established and the width of the egg band measured on the centreline of the search transects within the extent of the site (minimum three). Zero counts were recorded where these occurred such as when the egg patch was not continuous. Area of occupancy (AOO) was calculated as length $\mathrm{x}$ mean width. The total number of eggs present was calculated by sub-sampling patches. At each width measurement location, eggs were counted in a $10 \times 10 \mathrm{~cm}$ quadrat placed in the centre of the egg band. Productivity was calculated as mean egg density x AOO. 
Riparian land uses and management activities were mapped in the field using $0.075 \mathrm{~m}$ resolution postquake aerial photographs (Land Information New Zealand, 2016). Anthropogenic stressors were identified based on reported incompatibility with innanga spawning sites (Hickford \& Schiel, 2011a, 2011b; Mitchell, 1994). Areas affected were delineated using aerial photographs in the field and digitised for overlay analysis in QGIS v2.8.18 (QGIS Development Team, 2016). Four classes of land use activities were classified as threats to spawning habitat. These were bank stabilisation using engineered structures, invasive species control, mowing of recreation reserves, and vegetation removal for flood management. Threats from riverbank engineering were defined on the basis of surfaces devoid of any vegetation capable of supporting spawning (Mitchell, 1994). Examples include retaining walls, bridge abutments, riprap, and other bank stabilisation works. Invasive species control was classed as a threat where it involved spraying or extensive mechanical clearance (e.g., using scrub cutters, line trimmers \& similar). This recognises that vegetation suitable for spawning may take several months to recovery following clearance activities (Hickford \& Schiel, 2014). Mowing was classed as a threat where it resulted in short grass conditions at the top of the riverbank in the location of spawning habitat.

\section{Results}

\section{Pre-earthquake spawning distribution}

Eighteen pre-quake spawning studies spanning a 25 year period were identified, most of which involved surveys in both catchments. Thirteen of these had quantified spawning in the Avon and nine in the Heathcote (Table 1). In some years field surveys were conducted that did not find any spawning and these records are not shown in Table 1. In the Avon, most of the spawning occurrences have been in the Avondale Road area and often found a short distance upstream from the road bridge on the true right (Table 1). The maximum extent of pre-quake spawning sites recorded in any one year was $2000 \mathrm{~m}$. This also represents the maximum extent of the spawning reach based on all known records.

In the Heathcote, most of the records have been in the vicinity of Opawa Road (Table 1). Although the downstream limit of all records is c. $1 \mathrm{~km}$ further downstream this relates to only two observations of spawning below Opawa Road in the 25 year period. However, the first spawning recorded in the catchment was much further upstream $(>3 \mathrm{~km})$. At the time the river was under the influence of a floodway, constructed in 1986, that effectively shortened the length of the river. In 1994 a tidal barrage was installed to reduced saline intrusion and this resulted in a shift of c. $2 \mathrm{~km}$ downstream in the upstream limit of spawning (Taylor \& McMurtrie, 2004). These variations in the location of prequake sites complicate analyses of the extent of spawning habitat based on pooled records. However, the maximum extent of pre-quake spawning recorded in any one year was $1050 \mathrm{~m}$ in 2004 (Table 1). 
Table 1. Extent of īnanga spawning habitat utilised in the Avon and Heathcote Rivers over the period 1989 2014 from all known records.

\begin{tabular}{|c|c|c|c|}
\hline Year & Description & $\begin{array}{c}\text { Extent of } \\
\text { spawning }^{\dagger}(\mathbf{m})\end{array}$ & References \\
\hline \multicolumn{4}{|l|}{ Avon } \\
\hline 1989 & $\begin{array}{c}\text { TRB 40m reach downstream and upstream of Avondale Road } \\
\text { bridge }(\mathrm{ARb})\end{array}$ & 80 & $\begin{array}{l}\text { Meurk (1989); Taylor et al. } \\
\text { (1992) }\end{array}$ \\
\hline 1993 & TRB $15 \mathrm{~m}$ reach above $\mathrm{ARb}$ & 15 & Taylor (1996) \\
\hline 1996 & TRB $90 \mathrm{~m}$ reach above and $25 \mathrm{~m}$ reach below $\mathrm{ARb}$ & 115 & Taylor (1996) \\
\hline 1997 & TRB 90m reach above ARb & 90 & Taylor (1997) \\
\hline 1998 & TRB $70 \mathrm{~m}$ reach above and $20 \mathrm{~m}$ reach below $\mathrm{ARb}$ & 90 & Taylor (1998) \\
\hline 1999 & TRB $250 \mathrm{~m}$ reach above $\mathrm{ARb}$ & 250 & Taylor (1999) \\
\hline 2000 & $\mathrm{TRB}$ at $\mathrm{ARb}$ & 90 & Taylor (2000) \\
\hline 2004 & $\begin{array}{l}\text { TRB from Alloway Street to Orrick Crescent; TLB at Amelia } \\
\text { Rogers Reserve, above and below ARb, and at Corsers Stream }\end{array}$ & 1500 & Taylor and McMurtrie (2004) \\
\hline 2006 & $\begin{array}{l}\text { TLB Amelia Rogers Reserve } \\
\text { TLB Lake Kate Sheppard }\end{array}$ & 1070 & $\begin{array}{l}\text { University of Canterbury } \\
\text { unpubl. data }\end{array}$ \\
\hline 2007 & TRB from ARb to Sharlick Street and in Lake Kate Sheppard & 2000 & Taylor and Chapman (2007) \\
\hline 2008 & TRB above ARb & 250 & Hickford and Schiel (2014) \\
\hline 2010 & TRB above ARb & unknown & Taylor \& Main unpubl. data \\
\hline 2011 & TRB above ARb & 90 & Taylor and Blair (2011) \\
\hline \multicolumn{4}{|c|}{ Heathcote } \\
\hline 1989 & $\begin{array}{c}\text { TLB } 70 \mathrm{~m} \text { reach downstream and } 20 \mathrm{~m} \text { reach upstream of Wilsons } \\
\text { Road, TRB } 20 \mathrm{~m} \text { reach downstream of Wilsons Road }\end{array}$ & 90 & Eldon et al. (1989) \\
\hline 1991 & TRB 100m reach within King George V Reserve & 100 & Taylor et al. (1992) \\
\hline 1994 & TRB 30m reach below Opawa Road bridge (ORb) & 30 & Taylor (1994) \\
\hline 1995 & TRB 50m reach below ORb & 50 & Taylor (1995) \\
\hline 1998 & TRB 50m reach below $\mathrm{ORb}$ & 50 & Taylor (1998) \\
\hline 1999 & TRB from ORb to downstream of rail bridge & 70 & Taylor (1999) \\
\hline 2002 & TRB small patch in King George V Reserve & 10 & $\begin{array}{l}\text { University of Canterbury } \\
\text { unpubl. data }\end{array}$ \\
\hline 2004 & TRB in King George V Reserve, TLB and TRB below ORb & 1050 & Taylor and McMurtrie (2004) \\
\hline 2010 & TLB $12 \mathrm{~m}$ reach adjacent to Woolston Park & 12 & Taylor and Blair (2011) \\
\hline
\end{tabular}

Calculated as the distance between upstream and downstream limits of spawning as measured on the centreline of the mainstem for each river. Where spawning also occurred in tributaries the location of the confluence was used for this calculation. TRB $=$ true right bank. TLB $=$ true left bank

\section{Post-quake studies}

\section{Spawning extent}

A total of 85 spawning sites were identified in the 2015 post-quake survey. These were distributed along $2.4 \mathrm{~km}$ of riverbank in the Avon and $2.5 \mathrm{~km}$ in the Heathcote. In both rivers there were marked differences in the spawning distribution in comparison to previous records (Figure 2). In the Avon, the spawning reach had expanded approximately $250 \mathrm{~m}$ upstream and $180 \mathrm{~m}$ downstream of the previous extent. In the Heathcote, the changes were more pronounced with spawning recorded $1.5 \mathrm{~km}$ downstream of all previous records (Figure 2a). The 2016 survey identified a total of 101 spawning sites, some of which represented repeat use of 2015 sites. In the Avon, the upstream and downstream limits were very close to those recorded in 2015. In the Heathcote, the upstream limit was also similar to 2015 , but the spawning reach extended a further $400 \mathrm{~m}$ downstream (Figure $2 \mathrm{~b}$ ). 

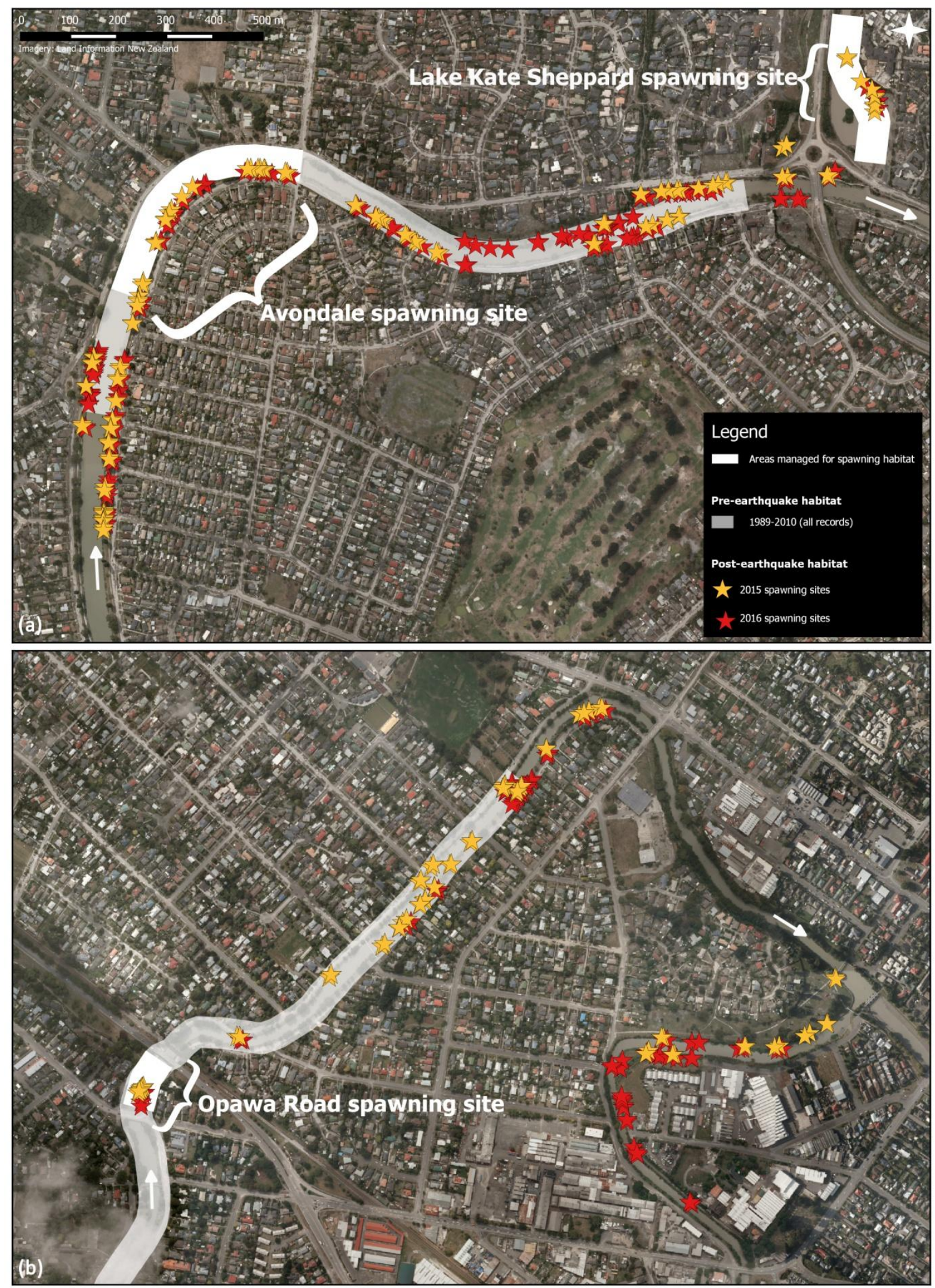

Figure 2. Post-quake īnanga spawning distribution overlaid on the maximum pre-quake extent of spawning from all known records. Well-known pre-quake spawning sites are shown. (a) Avon River (Ōtākaro). (b) Heathcote River (Ōpāwaho). 


\section{Distribution of threats and protected areas}

There are three areas managed to protect spawning habitat at well-known sites (Figure 3). The protection mechanisms include recognition in local authority plans and implementation of compatible riparian management on the ground. There is also a considerable reach in the lower Heathcote that is not subject to vegetation clearance for flood or reserves management purposes primarily due to being a neglected part of the river for maintenance. Part of this reach is characterised by tall woody riverbank vegetation and the remainder is downstream of the tidal barrage where there is less need for flood management-related channel maintenance (Figure 3b).

Threats from riverbank engineering occupied only a small proportion of the post-quake spawning extent in each river (Figure 3). Extensive channelization using gravel embankments is also found in the Avon. Although the area available for spawning may be reduced by these structures, they were not classified as threats based on observations of spawning if suitable vegetation co-occurred. Invasive plant species that have historically been the subject of spraying or mechanical clearance are widespread in the study area. In the Avon the major concern is Yellow Flag Iris (Iris pseudacorus). It is distributed throughout the spawning reach with the exception of sections engineered with gabion baskets and in Lake Kate Sheppard. This species is largely absent from the Heathcote and instead Reed Canary Grass (Phalaris arundinacea) is the major concern and is the dominant canopy species in many areas. In addition, Glyceria maxima and Rubus fruticosus are present there. There were no major eradication campaigns during the study period despite the severe level of infestation. With the exception of the protected areas (as above), vegetation control for flood management was conducted throughout the study area on a semi-regular basis consistent with previous years. This involves clearance of all bank vegetation using scrub cutters or line trimmers. Riparian mowing occurs in discrete areas in both river systems associated with a variety of parks and reserves in the river corridor (Figure 3).

\section{Area of occupancy of egg production}

In 2015, the total area of occupancy (AOO) of spawning habitat was $152.5 \mathrm{~m}^{2}$ in the Avon and $75.4 \mathrm{~m}^{2}$ in the Heathcote based on maximum figures recorded at each site across all four surveys. Total egg production was 11.8 million eggs (Avon $6.9 \times 10^{6}$, Heathcote $4.9 \times 10^{6}$ ). In 2016, egg production was higher (Avon $13.9 \times 10^{6}$, Heathcote $5.0 \times 10^{6}$ ) despite the survey period being reduced to only three months. The AOO was also higher in both rivers (Avon $472.9 \mathrm{~m}^{2}$, Heathcote $99.1 \mathrm{~m}^{2}$ ) although average egg densities were lower. The marked increase in AOO in the Avon was associated with several new large spawning sites that were not utilised in 2015 in addition to re-use of other sites. In both years, $\mathrm{AOO}$ and productivity were not evenly distributed across the study area. High production was not always correlated with AOO due to differences in egg densities (Figure 4). Egg densities of $>10$ eggs cm${ }^{-2}$ were recorded at several sites with the highest being $13.5 \mathrm{~cm}^{-2}$. 
bioRxiv preprint doi: https://doi.org/10.1101/229872; this version posted December 8, 2017. The copyright holder for this preprint (which was not certified by peer review) is the author/funder, who has granted bioRxiv a license to display the preprint in perpetuity. It is made available under aCC-BY-ND 4.0 International license.
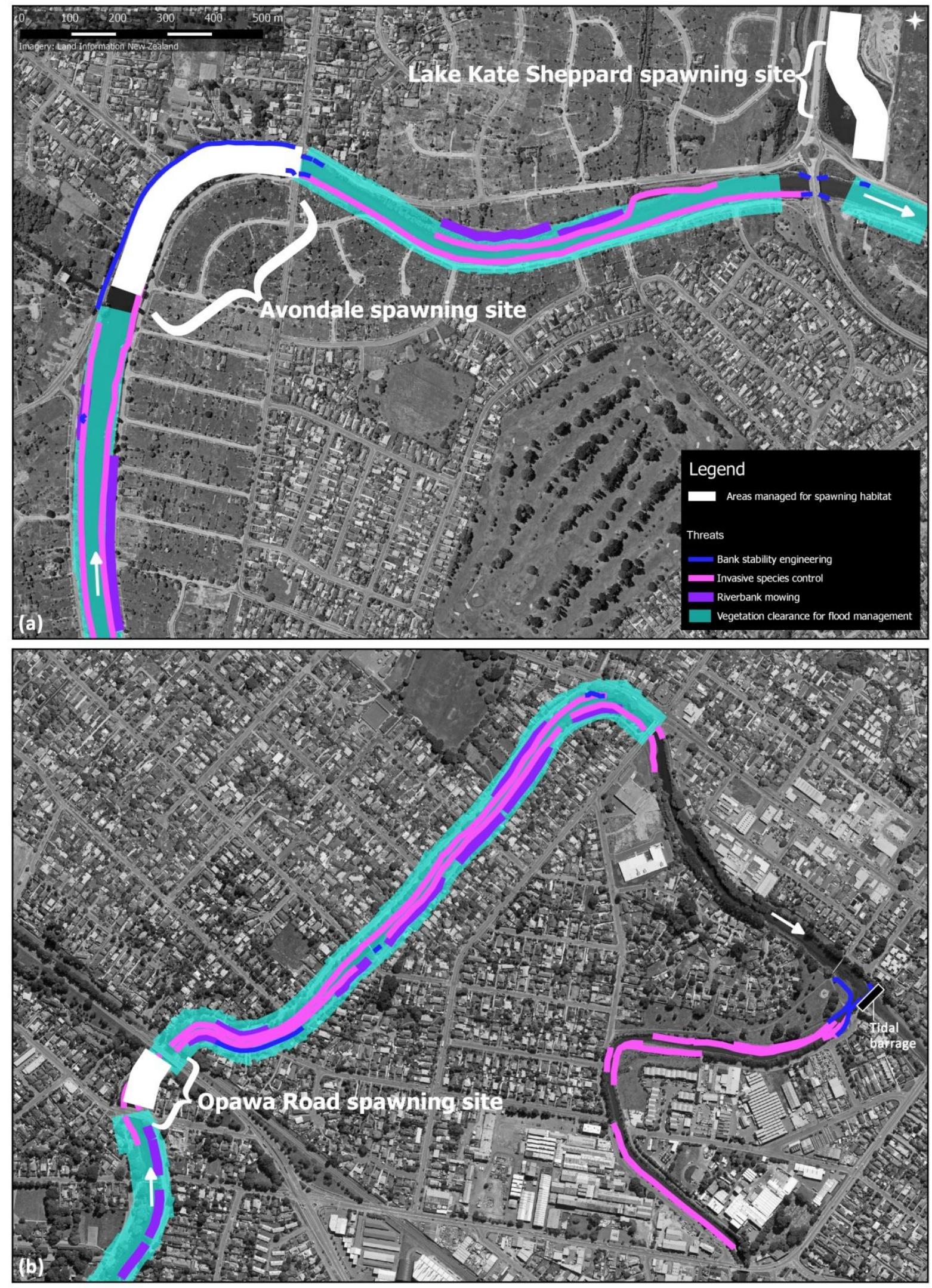

Figure 3. Distribution of post-quake anthropogenic threats associated with riparian land uses and management activities in the study area. (a) Avon River. (b) Heathcote River. 

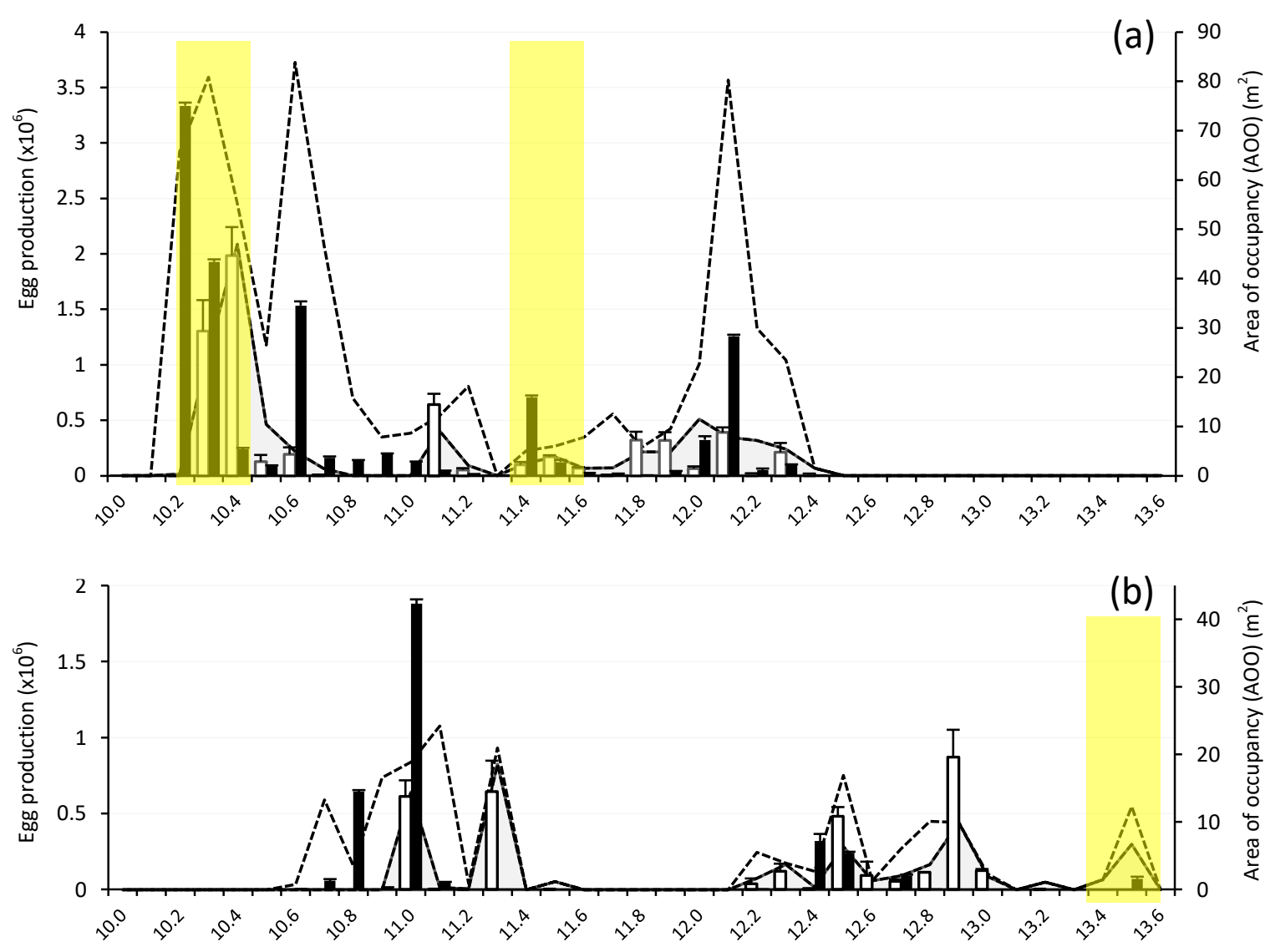

Distance from river mouth $(\mathrm{km})$

Figure 4. Post-quake area of occupancy (AOO) and productivity of innanga spawning sites presented as aggregated data for contiguous $100 \mathrm{~m}$ reaches of the Avon and Heathcote Rivers. Egg production is shown as the total recorded in the surveys conducted each year $(n=4,2015 ; n=3,2016)$. AOO is presented as the maximum area occupied by spawning sites each year. River kilometres are measured from the entrance into the Avon-Heathcote Estuary / Ihutai following the main channel lines for each river. Error bars are standard errors of the mean.

\section{Effectiveness of protected areas}

In the Avon, the proportion of the AOO occurring in protected areas was 70\% in 2015. In 2016 this figure had decreased to only $28 \%$ reflecting many new sites discovered in other locations. In the Heathcote, the proportion of AOO protected was very low $(11 \%$ and $6 \%$ for the two years respectively) reflecting that the majority of spawning sites were discovered at sites never previously known for spawning. Post-quake egg production was considerable in the unprotected areas (Figure 5). In the Avon, the proportion of egg production outside the protected areas was $28 \%$ in 2015 and 38\% in 2016 (Figure 5a).In the Heathcote, $82 \%$ of egg production occurred outside of the protected areas in 2015 and $98 \%$ in 2016 (Figure 5b). On average across the two years of post-quake studies, only $4.5 \%$ of the spawning reach was protected in the Heathcote and 27.6\% in the Avon (Figure 6). Vegetation clearance for reserves and flood management purposes was observed at many of the unprotected spawning sites after egg deposition had occurred (see Supplementary Material). Repeat egg surveys at some of these sites after the vegetation clearance indicated close to $100 \%$ egg mortality. This is consistent with previous studies (Hickford \& Schiel, 2014). 
bioRxiv preprint doi: https://doi.org/10.1101/229872; this version posted December 8, 2017. The copyright holder for this preprint (which was not certified by peer review) is the author/funder, who has granted bioRxiv a license to display the preprint in perpetuity. It is made available under aCC-BY-ND 4.0 International license.
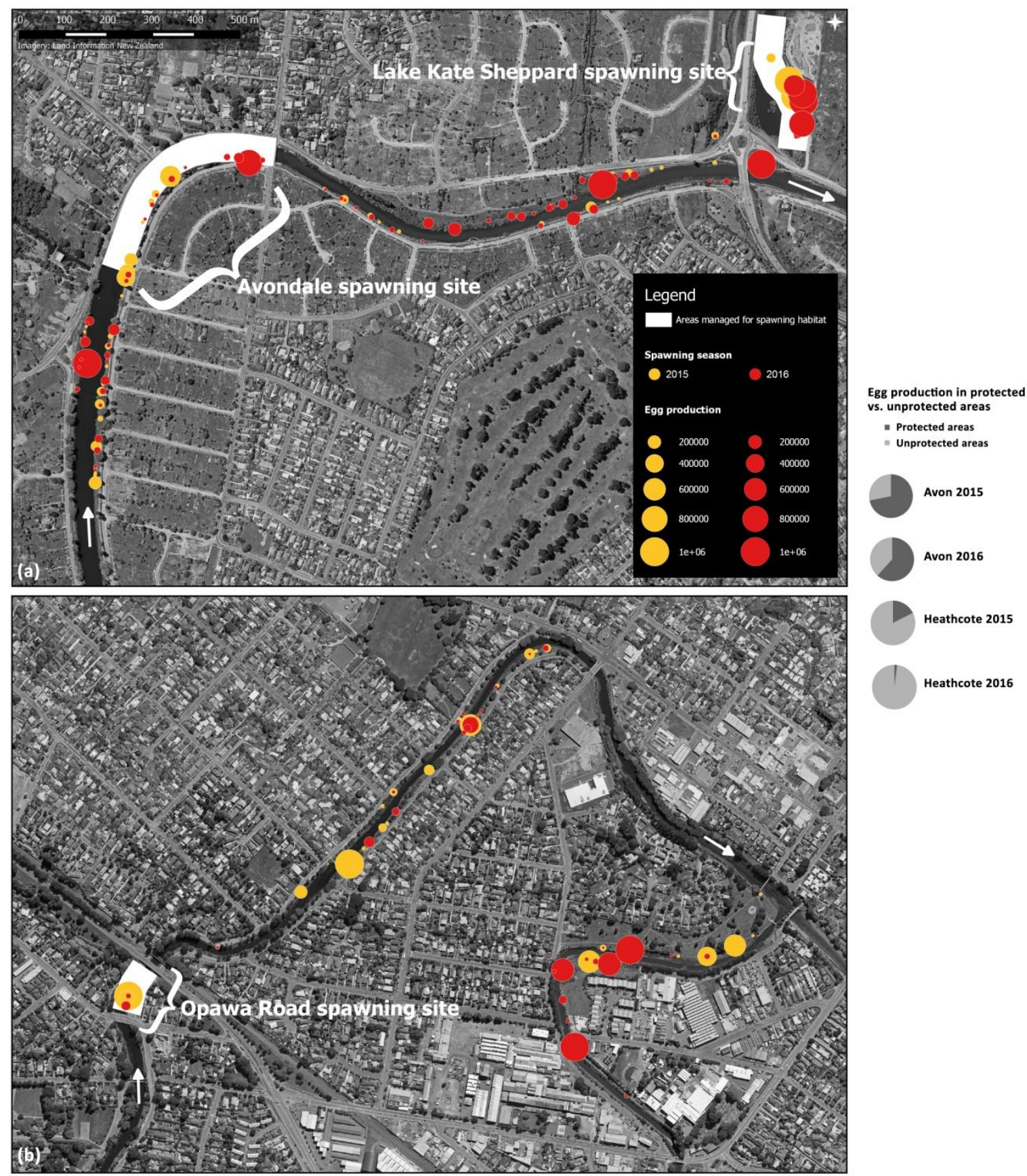

Figure 5. Spatial distribution of post-quake īnanga egg production and proportion of post-quake production that occurred in protected areas. (a) Avon River (Ōtākaro). (b) Heathcote River (Ōpāwaho). 


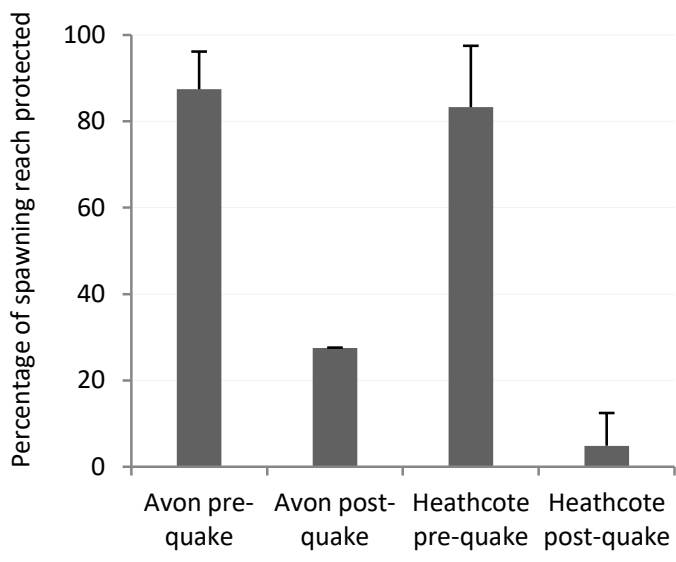

Figure 6. Percentage of the known innanga spawning reach in protected areas in the Avon and Heathcote rivers before and after the 2010-11 Canterbury earthquake sequence. Error bars are standard errors of the mean for the periods.

\section{Discussion}

\section{Evidence for habitat migration}

The Christchurch waterways have one of the most extensive records of innanga spawning site surveys for any catchment in New Zealand (Taylor, 2002). However, variability in the search effort and methodologies used in the historical surveys are among the sources of uncertainty in characterising the pre-quake baseline. Data used were restricted to confirmed spawning site locations as indicated by the observation of eggs in riparian vegetation. Records of shoaling adult fish in the spawning season are also present in the national database and technical reports and often associated with the location of spawning. These records were considered to be unreliable for quantifying spawning habitat due the mobility of shoals and unknown timing of spawning. In the Avon, the majority of historical spawning has been recorded at the Avondale site. In this vicinity the extent of spawning reach steadily increased since discovery of the site in 1989 with assistance from protection from mowing (Taylor, 1999). In 2004, new sites were identified further downstream in the mainstem, and in 2006 spawning was found at Lake Kate Sheppard and then regularly thereafter (Figure 2a). This is an area of restored riparian margins in a tributary waterway and lake system located close to the mainstem. In the Heathcote, the pre-quake distribution has shifted by up the $3 \mathrm{~km}$ over the 25 years for which records are available. This has been associated with engineering of the floodway (Taylor, 1998). However, spawning has centred on the Opawa Road site since 2004. Only two sites have been recorded further downstream in all known records. Earthquake-induced migration of habitat a further $1.5 \mathrm{~km}$ downstream in 2015 and $1.9 \mathrm{~km}$ in 2016 represents a major change in spawning habitat distribution.

\section{Effectiveness of protected areas}

A high proportion of inanga spawning now occurs outside of the areas established for protection. Risk exposure is now greater due to the co-concurrence of habitat with anthropogenic threats. Earthquakeinduced change is not the source of heightened vulnerability per se. Rather, this is an effect of natural dynamics that have increased exposure to pre-existing stressors. These activities are now threats that require management to achieve conservation objectives. Mowing of vegetation within riparian reserves co-occurs with several spawning sites in both river systems. It is a particular issue where the 
spring high tide water levels are sufficient to inundate riparian terraces. These provide locations where spawning habitat may be relatively expansive in comparison to areas with steeper topography. Vegetation clearance using scrub bars also occurs on the bank face throughout the study area for flood management purposes with the exception of locations specifically managed for inanga spawning, being the three established pre-quake spawning sites (Figure 4). Compared to reserve maintenance activities, vegetation clearance for flood management affects the upper intertidal zone of the waterway margin. At many locations this results in a direct overlap with the spawning habitat elevation band. High egg mortality from mowing and grazing has been previously reported (Hickford \& Schiel, 2014). This is believed to be mostly attributable to UV irradiation or the drying out of eggs (Hickford et al., 2010; Hickford \& Schiel, 2011b). Recovery from vegetation clearance can take many months, with the re-establishment of sufficient cover being a critical factor (Hickford \& Schiel, 2014). In addition, these activities may occur after eggs have been laid in vegetation that would otherwise have been suitable for spawning. This was observed at many of the spawning sites recorded in this study and is particularly problematic for conservation. Due to the gregarious behavioural ecology of G. maculatus (Benzie, 1968a; McDowall, 1990), the majority of spawning production is typically supported by only a few sites in the catchment in each spawning event. This contributes to the vulnerability of spawning to stochastic events. Anthropogenic threats affecting these highly productive sites may have a large impact on the total egg production on a seasonal basis.

\section{Lessons for adaptive management}

This case illustrates important principles for managing subtle yet widespread change. Habitat migration was not detected by conservation management practitioners. Pre-disturbance land-use activities had continued without adaptation exposing the habitat to increased risk despite its apparent expansion. Adaptive management responses are needed to control anthropogenic stressors in areas that have now become innanga spawning habitat. Achieving this requires further work to develop solutions that accommodate other necessary or desirable activities in the riparian zone. Although historical AOO figures are not available, the post-quake studies indicate that in both catchments the extent of spawning habitat is now greater than all previous records. This is a positive finding and suggests a potential improvement in the opportunities available for accommodating incompatible activities through tools such as spatial planning. If these are addressed and solutions identified, conservation gains could be secured in terms of increasing the area of protecting habitat and ultimately improved egg production.

Implementation of statutory protection adds another dimension to this case. It is important to note that protection of the post-quake habitat is a legislative requirement. However, conservation policy frequently suffers from implementation gaps in practice (Knight et al., 2008), often resulting from a lack of attention to methods that are effective in the societal context (Knight et al., 2010). Dynamic environments and spatio-temporal variation create additional challenges for the design of effective methods. Our results illustrate that investments in information are a pivotal activity for achieving this in practice. Regular monitoring or predictive modelling could provide solutions for evaluating change, but they must be coupled with appropriate responses to facilitate adaptive approaches.

Lastly, the effects described here are an example of landscape-scale responses to infrequent tectonic dynamics. They have likely been mediated by hydrological and salinity changes together with smaller-scale effects on ground surfaces in the riparian zone. In the Heathcote, the magnitude of horizontal shift suggests that salinity effects may be involved and this deserves further investigation. Despite these unknowns, the opportunity for learning is clear. Post-earthquake studies present opportunities to evaluate many aspects of socio-ecological systems for impacts and associated 
responses. Not only are tectonic events relatively common in evolutionary time, they may exert similar effects to climate change through influencing water levels and salinity gradients relative to existing topography (Beavan \& Litchfield, 2012). Earthquakes present unique and important opportunities to study vulnerable ecosystems and provide examples of real-life adaptation in action. In turn, this may assist in developing methods to achieve conservation objectives and avoid implementation failures in the face of ongoing change.

\section{Acknowledgements}

We thank Mark Taylor, Shelley McMurtrie and Colin Meurk for providing historical records. We acknowledge the many volunteers and staff of the Waterways Centre for Freshwater Research and Marine Ecology Research Group who assisted with the post-quake field studies, and local government staff for information on riparian management activities. Funding was provided by the Ngāi Tahu Research Centre, Institute of Professional Engineers of New Zealand Rivers Group, Brian Mason Scientific and Technical Trust, and a New Zealand Ministry of Business, Innovation and Employment grant (C01X1002) in conjunction with the National Institute of Water and Atmospheric Research.

\section{References}

Beavan, R. J., \& Litchfield, N. J. (2012). Vertical land movement around the New Zealand coastline: implications for sea-level rise. GNS Science Report 2012/29. Lower Hutt.

Benzie, V. (1968a). Some ecological aspects of the spawning behaviour and early development of the common whitebait Galaxias maculatus attenuatus (Jenyns). Proceedings of the New Zealand Ecological Society, 15, 31-39.

Benzie, V. (1968b). Stages in the normal development of Galaxias maculatus attenuatus (Jenyns). New Zealand Journal of Marine and Freshwater Research, 2(4), 606-627.

Burnet, A. M. R. (1965). Observations on the spawning migrations of Galaxias attenuatus. New Zealand Journal of Science, 8, 79-87.

Eldon, G. A., Kelly, G. R., Bonnett, M. L., \& Taylor, M. J. (1989). Fisheries survey of the Heathcote River, January 1989. New Zealand Freshwater Fisheries Report, 111, 50.

Goodman, J. M., Dunn, N. R., Ravenscroft, P. J., Allibone, R. M., Boubée, J. A. T., David, B. O., . . . Rolfe, J. R. (2014). Conservation status of New Zealand freshwater fish, 2013. New Zealand Threat Classification Series. Wellington: Department of Conservation., 12pp.

Hickford, M. J. H., Cagnon, M., \& Schiel, D. R. (2010). Predation, vegetation and habitat-specific survival of terrestrial eggs of a diadromous fish, Galaxias maculatus (Jenyns, 1842). Journal of Experimental Marine Biology and Ecology, 385(1-2), 66-72. doi:10.1016/j.jembe.2010.01.010

Hickford, M. J. H., \& Schiel, D. R. (2011a). Population sinks resulting from degraded habitats of an obligate life-history pathway. Oecologia, 166(1), 131-140. doi:10.1007/s00442-010-1834-7

Hickford, M. J. H., \& Schiel, D. R. (2011b). Synergistic interactions within disturbed habitats between temperature, relative humidity and UVB radiation on egg survival in a diadromous fish. PLoS ONE, 6(9), e24318. doi:doi:10.1371/journal.pone.0024318

Hickford, M. J. H., \& Schiel, D. R. (2014). Experimental rehabilitation of degraded spawning habitat of a diadromous fish, Galaxias maculatus (Jenyns, 1842) in rural and urban streams. Restoration Ecology, 22(3), 319-326. 
Hughes, M. W., Quigley, M. C., van Ballegooy, S., Deam, B. L., Bradley, B. A., Hart, D. E., \& Measures, R. (2015). The sinking city: Earthquakes increase flood hazard in Christchurch, New Zealand. GSA Today, 25(3-4), 4-10.

Jolly, D., \& Ngā Papatipu Rūnanga Working Group. (2013). Mahaanui Iwi Management Plan 2013. Mahaanui Kurataiao Ltd. Ötautahi Christchurch.

Kirk, R. M. (1979). Dynamics and management of sand beaches in southern Pegasus Bay. Morris and Wilson Consulting Engineers Limited. Christchurch.

Knight, A. T., Cowling, R. M., Difford, M., \& Campbell, B. M. (2010). Mapping human and social dimensions of conservation opportunity for the scheduling of conservation action on private land. Conservation Biology, 24(5), 1348-1358. doi:10.1111/j.1523-1739.2010.01494.x

Knight, A. T., Cowling, R. M., Rouget, M., Balmford, A., Lombard, A. T., \& Campbell, B. M. (2008). Knowing but not doing: selecting priority conservation areas and the research-implementation gap. Conservation biology : the journal of the Society for Conservation Biology, 22(3), 610617. doi:10.1111/j.1523-1739.2008.00914.x

Land Information New Zealand. (2016). Christchurch 0.075m Urban Aerial Photos (2015-16). Imported on Oct. 3, 2016 from 6993 GeoTIFF sources in NZGD2000 / New Zealand Transverse Mercator 2000.

Lang, M., Orchard, S., Falwasser, T., Rupene, M., Williams, C., Tirikatene-Nash, N., \& Couch, R. (2012). State of the Takiwā 2012 -Te Ähuatanga o Te Ihutai. Cultural Health Assessment of the Avon-Heathcote Estuary and its Catchment. Christchurch: Mahaanui Kurataiao Ltd. 41pp.

McDowall, R. M. (1984). The New Zealand whitebait book. Wellington: Reed.

McDowall, R. M. (1990). New Zealand freshwater fishes: A natural history and guide. Auckland: Heinemann Reed.

McDowall, R. M. (1992). Particular problems for the conservation of diadromous fish. Aquatic Conservation: Marine and Freshwater Ecosystems, 2(4), 351-355. doi:10.1002/aqc.3270020405

McDowall, R. M., \& Charteris, S. C. (2006). The possible adaptive advantages of terrestrial egg deposition in some fluvial diadromous galaxiid fishes (Teleostei : Galaxiidae). Fish and Fisheries, 7(3), 153-164. doi:10.1111/j.1467-2979.2006.00217.x

Measures, R., Hicks, M., Shankar, U., Bind, J., Arnold, J., \& Zeldis, J. (2011). Mapping earthquake induced topographical change and liquefaction in the Avon-Heathcote Estuary. Environment Canterbury Report No. U11/13. Christchurch: Environment Canterbury. 28pp.

Meurk, C. D. (1989). Vegetation of the inanga spawning grounds on the banks of the lower Avon River. Botany Division DSIR. Christchurch.

Mitchell, C. P. (1994). Whitebait spawning ground management. New Zealand Department of Conservation, Science and Research Series, 69, 1-23.

Mitchell, C. P., \& Eldon, G. A. (1991). How to locate and protect whitebait spawning grounds. Rotorua: Freshwater Fisheries Centre., 49pp.

Orchard, S. (2014). Potential roles for coastal protected areas in disaster risk reduction and climate change adaptation: a case study of dune management in Christchurch, New Zealand. In R. Murti \& C. Buyck (Eds.), Safe Havens: Protected Areas for Disaster Risk Reduction and Climate Change Adaptation. Gland, Switzerland: Internation Union for the Conservation of Nature. p83-93.

Orchard, S., \& Hickford, M. J. H. (2017). Census survey approach to quantifying īnanga spawning habitat for conservation and management. New Zealand Journal of Marine and Freshwater Research, 51(4), e. doi:10.1080/00288330.2017.1392990.

QGIS Development Team. (2016). QGIS Geographic Information System. Open Source Geospatial Foundation Project. http://qgis.osgeo.org. 
Quigley, M. C., Hughes, M. W., Bradley, B. A., van Ballegooy, S., Reid, C., Morgenroth, J., . . . Pettinga, J. R. (2016). The 2010-2011 Canterbury Earthquake Sequence: Environmental effects, seismic triggering thresholds and geologic legacy. Tectonophysics, 672-673, 228-274. doi:10.1016/j.tecto.2016.01.044

Regenerate Christchurch. (2017). Outline for the Ötākaro / Avon River Corridor Regeneration Plan. Christchurch: Regenerate Christchurch.

Richardson, J., \& Taylor, M. J. (2002). A guide to restoring inanga habitat. NIWA Science and Technology Series, 50, 1-29.

Taylor, M. J. (1994). Inanga spawning ground enhancement, Heathcote River. National Institute of Water \& Atmospheric Research Ltd. Christchurch.

Taylor, M. J. (1995). Inanga spawning on the Heathcote River. National Institute of Water \& Atmospheric Research Ltd. Christchurch.

Taylor, M. J. (1996). Inanga spawning in the Avon and Heathcote Rivers. National Institute of Water and Atmospheric Research Ltd. Christchurch.

Taylor, M. J. (1997). Inanga spawning activity on the Avon and Heathcote Rivers. NIWA client report CHC97/57. National Institute of Water and Atmospheric Research Ltd. Christchurch.

Taylor, M. J. (1998). Inanga spawning in the Avon and Heathcote Rivers, April 1998. NIWA client report CHC98/42. National Institute of Water and Atmospheric Research Ltd. Christchurch.

Taylor, M. J. (1999). Inanga spawning on the Avon and Heathcote Rivers, 1999. National Institute of Water \& Atmospheric Research Ltd. Christchurch.

Taylor, M. J. (2000). Inanga spawning in the city region during the year 2000. National Institute of Water \& Atmospheric Research Ltd. Christchurch.

Taylor, M. J. (2002). The national inanga spawning database: trends and implications for spawning site management. Science for Conservation 188. Wellington: Department of Conservation., 37pp.

Taylor, M. J., \& Blair, W. (2011). Effects of seismic activity on inaka spawning grounds on city rivers. Aquatic Ecology Limited. Christchurch.

Taylor, M. J., Buckland, A. R., \& Kelly, G. R. (1992). South Island inanga spawning surveys, 19881990. New Zealand Freshwater Fisheries Report No. 133. Ministry of Agriculture and Fisheries. Christchurch.

Taylor, M. J., \& Chapman, E. (2007). Monitoring of fish values; inanga and trout spawning. AEL Report No. 54. Christchurch: Aquatic Ecology Limited., 22pp.

Taylor, M. J., \& McMurtrie, S. E. (2004). Inanga spawning gounds on the Avon and Heathcote rivers. Aquatic Ecology Ltd. Christchurch.

White, P. A., Goodrich, K., Cave, S., \& Minni, G. (2007). Waterways, swamps and vegetation of Christchurch in 1856 and baseflow discharge in Christchurch city streams. GNS Science Consultancy Report 2007/103. Taupo. 


\section{Supplementary Material}

Table S1. Survey periods and tidal cycle data for post-earthquake G. maculatus spawning surveys.

\begin{tabular}{llccccc}
\hline Year & $\begin{array}{l}\text { Month of } \\
\text { spawning }\end{array}$ & $\begin{array}{l}\text { Peak tidal } \\
\text { cycle start }\end{array}$ & $\begin{array}{l}\text { Peak tidal } \\
\text { cycle end }\end{array}$ & $\begin{array}{c}\text { Peak tidal } \\
\text { height* }(\mathbf{m})\end{array}$ & \multicolumn{2}{c}{ Survey period } \\
2015 & February & Feb 22 & Feb 25 & 2.6 & Mar 3-6 & Mar 7 -15 \\
\cline { 5 - 6 } 2015 & March & Mar 20 & Mar 23 & 2.6 & $\begin{array}{c}\text { Mar 29 }- \\
\text { Apr 3 }\end{array}$ & Apr 4-11 \\
2015 & April & Apr 18 & Apr 20 & 2.6 & Apr 26-30 & May 1-8 \\
2015 & May & May 17 & May 19 & 2.6 & May 26-30 & Jun 1-6 \\
2016 & February & Feb 10 & Feb 14 & 2.5 & Feb18-22 & Feb 23-29 \\
2016 & March & Mar 10 & Mar 13 & 2.6 & Mar18-22 & Mar23-97 \\
2016 & April & Apr 7 & Apr 11 & 2.6 & Apr 14-18 & Apr 19-26 \\
\hline
\end{tabular}

* predicted tide levels above Chart Datum at Port of Lyttelton (Lat. 43 $36^{\prime}$ S Long. 172 $43^{\prime}$ E) (Source: Land Information New Zealand). 
bioRxiv preprint doi: https://doi.org/10.1101/229872; this version posted December 8,2017 . The copyright holder for this preprint (which was not certified by peer review) is the author/funder, who has granted bioRxiv a license to display the preprint in perpetuity. It is made available under aCC-BY-ND 4.0 International license.

Table S2. Habitat quality classes.

\begin{tabular}{llll}
\hline Class & $\begin{array}{l}\text { Quality of habitat for } \\
\text { Supporting spawning }\end{array}$ & $\begin{array}{l}\text { Expected egg } \\
\text { mortality rate }\end{array}$ & Criteria \\
\hline $\mathbf{1}$ & Poor & High & $\begin{array}{l}\text { Vegetation cover }<100 \% \\
\text { or stem density }<0.2 \mathrm{~cm}^{-2}\end{array}$ \\
$\mathbf{2}$ & Moderate & Moderate & $\begin{array}{l}\text { Vegetation cover } 100 \% \\
\text { Stem density }>0.2 \mathrm{~cm}^{-2}\end{array}$ \\
& & & Aerial root mat depth $<0.5 \mathrm{~cm}$ \\
& \multirow{3}{*}{ Good } & Low & Vegetation cover $100 \%$ \\
& & & Stem density $>0.2 \mathrm{~cm}^{-2}$ \\
& & & Aerial root mat depth $>0.5 \mathrm{~cm}$ \\
\hline
\end{tabular}

\section{Classification schema}

A. Vegetation cover $<100 \%$ Class 1

Vegetation cover $>100 \%$ Class 2 or 3

B. Stem density $<0.2 \mathrm{~cm}^{-2}$ Class 1

Stem density $>0.2 \mathrm{~cm}^{-2}$ Class 2 or 3

C. Aerial root mat depth $<0.5 \mathrm{~cm}$ Class 2

Aerial root mat depth $>0.5 \mathrm{~cm}$ Class 3 
bioRxiv preprint doi: https://doi.org/10.1101/229872; this version posted December 8, 2017. The copyright holder for this preprint (which
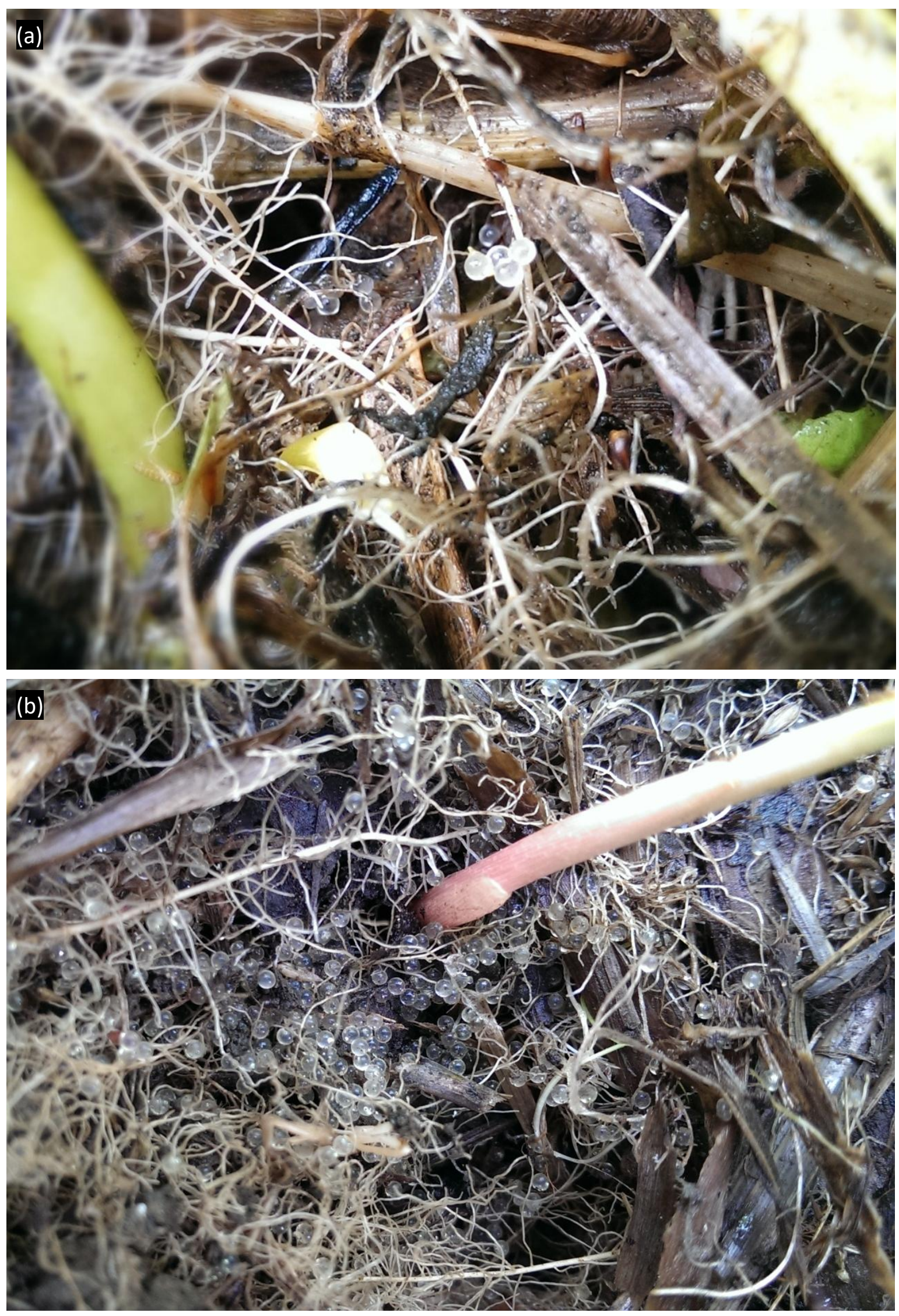

Figure S1. (a) G. maculatus eggs laid in riparian vegetation in the Heathcote River, February 2015. Each egg is approximately $1 \mathrm{~mm}$ in diameter. (b) An example of high egg densities at the Avondale site in March 2016. 
bioRxiv preprint doi: https://doi.org/10.1101/229872; this version posted December 8, 2017. The copyright holder for this preprint (which was not certified by peer review) is the author/funder, who has granted bioRxiv a license to display the preprint in perpetuity. It is made available under aCC-BY-ND 4.0 International license.

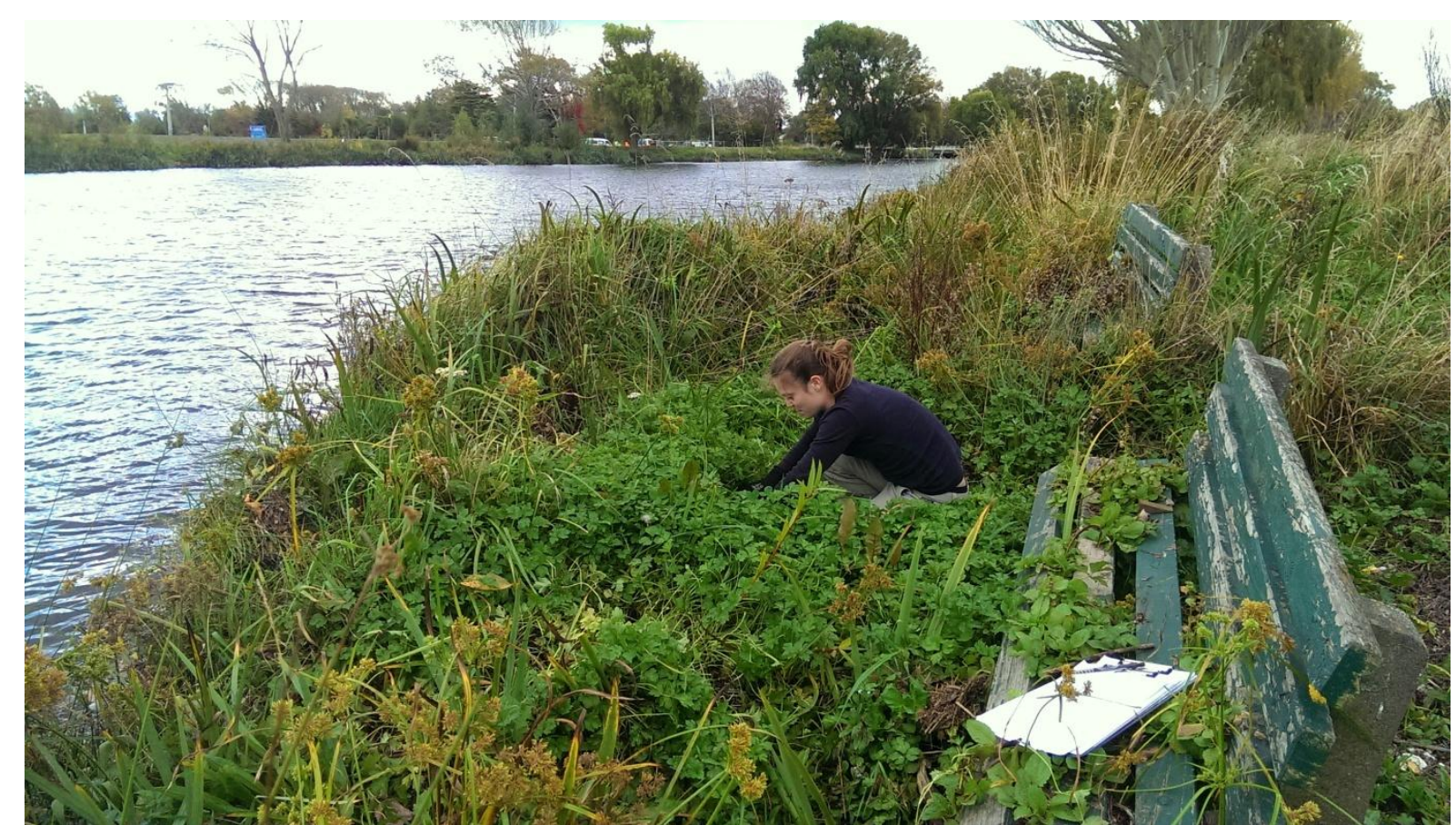

Figure S2. An example of good quality spawning habitat in the Avon River. In this part of the catchment ground levels had dropped by approximately $0.5 \mathrm{~m}$ as result of earthquake-induced subsidence and lateral spread. Prior to the earthquakes these overgrown park benches were considerably closers to the waters' edge.

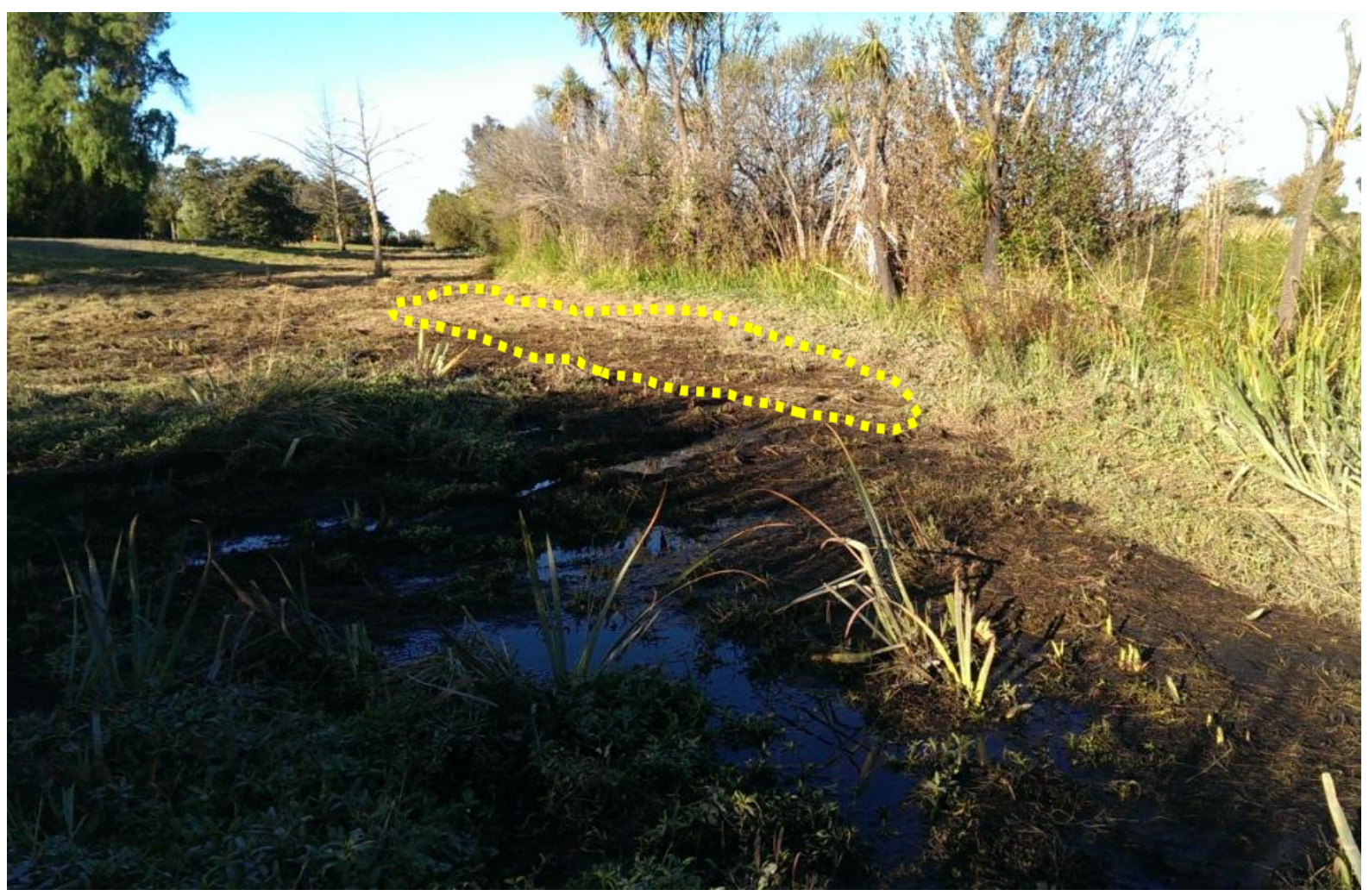

Figure S3. Example of a spawning site affected by mowing in a recreation reserve in the Avon catchment. The dotted line shows the area of occupancy (AOO) prior to mowing in March 2015. Egg mortality is close to $100 \%$ in these situations. 
bioRxiv preprint doi: https://doi.org/10.1101/229872; this version posted December 8, 2017. The copyright holder for this preprint (which was not certified by peer review) is the author/funder, who has granted bioRxiv a license to display the preprint in perpetuity. It is made available under aCC-BY-ND 4.0 International license.
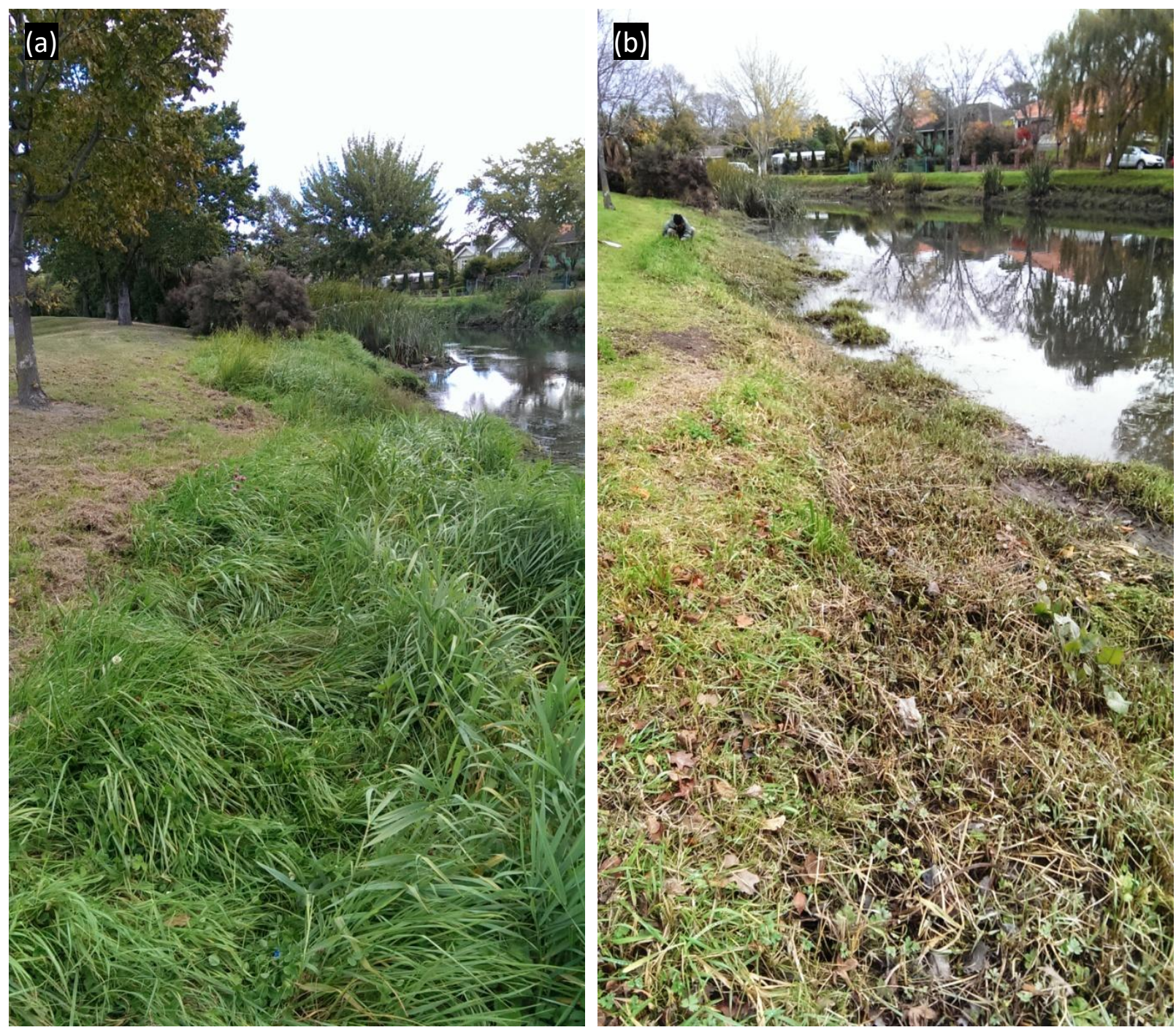

Figure S4. Example of vegetation clearance for flood management. (a) Spawning site in the Heathcote River in March 2015 at which 118, 000 eggs were present (located in the long grass). Mowing of a recreation reserve can also be seen in this image but did not affect the majority of the spawning site which was located lower on the bank face. (b) The same site in early May 2015 showing typical conditions following clearance of vegetation for flood management using line trimmers. This management regime is regularly applied to a large proportion of the study area. 